\title{
PENGARUH TERAPI RELAKSASI BENSON TERHADAP TEKANAN DARAH SISTOLE PADA LANSIA DENGAN HIPERTENSI
}

\section{THE EFFECT OF BENSON RELAXATION THERAPY ON SISTOLE BLOOD PRESSURE IN ELDERLY WITH HYPERTENSION}

\author{
Febriyanti', Viki Yusri², Nova Fridalni ${ }^{3}$ \\ Program Studi Ilmu Keperawatan STIKes mercubaktijaya Padang \\ febrianti160911@gmail.com,vikiyusri80@gmail.com,novafridalni@gmail.com
}

\begin{abstract}
ABSTRAK : Hipertensi merupakan peningkatan tekanan darah diatas normal. Hipertensi mempunyai hubungan yang sangat erat dengan lansia, sehingga dapat menyebabkan komplikasi dan penyakit kardiovaskuler bila tidak ditangani dengan tepat. Hipertensi sebagian besar $80 \%$ di sebabkan oleh faktor idiopatik, sedangkan faktor yang dapat menjadi pencetus hipertensi sekitar $24 \%$ adalah perokok berat, $16 \%$ diabetes mellitus, dan $62 \%$ karena kolesterol tinggi. Faktor kebiasaan lain yang dapat mengakibatkan hipertensi adalah pecandu alkohol, stress tinggi, makanan tinggi natrium dan kurangnya aktifitas. Seseorang yang menderita hipertensi memiliki resiko stroke tujuh kali lebih besar dibandingkan dengan seseorang yang memiliki tekanan darah normal atau rendah. Terapi non farmakologi untuk menurunkan tekanan darah salah satunya melakukan terapi relaksasi Benson. Tujuanpenelitian ini adalah untuk mengetahui pengaruh terapi relaksasi Benson terhadap tekanan darah sistole pada lansia dengan hipertensi di Kelurahan Lubuk Lintah RW I Kecamatan Kuranji Padang. Jenis penelitian ini menggunakan desain penelitian pre eksperimen dengan rancangan one group pretest posttest, dengan teknik pengambilan sampel purposive sampling. Pengolahan data dengan uji t-test. Hasil penelitian menunjukkan bahwa terdapat pengaruh terapi Benson terhadap penurunan tekanan darah pada lansia yang mengalami hipertensi dengan nilai p-value 0,00. Lansia diharapkan mampu mengontrol tekanan darahnya sendiri terutama yang dengan menerapkan pola hidup sehat dan melakukan terapi relaksasi Benson.
\end{abstract}

Kata Kunci : Tekanan darah, sistole, lansia, terapi relaksasi Benson

ABSTRACT : Hypertension is an increase in blood pressure above normal. Hypertension has a very close relationship with elderly, so that it can cause complications and cardiovasculerdisesase if not handled properly. Mostly 80\% of hypertension is caused by idiopatic factors, while the factors thatcan trigger hypertension around $24 \%$ are heavy smokers, $16 \%$ diabetes mellitus and $62 \%$ due to high cholesterol.Oteher habitual factors taht can cause hypertension are alcoholics, high stress, high sodium foods and lack of activity. Someone who has a hyptertension has a seven times grater risk of stroke compared to someone who has normal or low blood pressure. Nonpharmacological therapy to reduce blood pressure, one of which is Bensons's relaxation therapy. The purpose of this study was to determine the effect of Bensons's relaxation therapy on systolic blood pressure in the elderly with hypertension in KelurahanLubuklintah RW I, Kuranji district Padang. This type of research uses a pre-experimental research design with a one group pretestspostest design, with a purpose sampling technique. Data processing with $t$-test. The result showed that there was an effect of Benson's relaxation therapy on dreacresing blood pressure in elderly who had hypertension with p-value 0,00. The elderly are expected to be able to control their own blood pressure, especially those with hypertension by implementing a healthy lifestyle and doing Benson's relaxation therapy

Keywords : Blood pressure, cystole, elderly, Benson's relaxation therapy 


\section{A. PENDAHULUAN}

Menurut World Health Organization (WHO, 2015) prevalensi hipertensi di negara maju maupun negara berkembang masih tergolong tinggi, prevalensi hipertensi di negara maju adalah sebesar $35 \%$ dari populasi dewasa dan prevalensi hipertensi di negara berkembang sebesar $40 \%$ dari populasi dewasa. Secara global prevalensi hipertensi di Amerika sebesar 35\%, di kawasan Eropa sebesar 41\%, dan Australia sebesar 31,8\%. Prevalensi hipertensi pada kawasan Asia Tenggara adalah sebesar 37\%. Prevalensi tertinggi terdapat pada kawasan Afrika yaitu sebesar 46\%. Jumlah lansia di dunia lebih dari 629 juta jiwa. Di Indonesia jumlah penduduk lanjut usia (60 tahun keatas) pada tahun 2005 mencapai 16,80 juta orang. Angka ini naik menjadi 18,96 juta orang pada tahun 2007 dan menjadi 19,3 juta orang pada tahun 2009 dan pada tahun 2010 jumlah penduduk lansia mencapai 19 juta orang, pada tahun 2013 jumlah lansia mencapai 18,78 juta jiwa. WHO memprediksi jumlah penduduk lansia pada tahun 2020 mencapai 28,8 juta dari jumlah penduduk Indonesia.

Di Sumatera Barat mengalami peningkatan dari 5,45\% menjadi 25,9\% pada tahun 2013. Seiring bertambahnya usia maka fungsi-fungsi tubuh akan mengalami penurunan dan mengakibatkan para lansia jatuh dalam kondisi sakit. Penurunan fungsi-fungsi tubuh ini di sebut dengan proses degeneratif. Salah satu proses degeneratif yang terjadi adalah pada sistem kardiovaskuler. Prevalensi hipertensi lansia di Indonesia sebesar 45,9\% untuk umur 55-64 tahun, 57\% umur 65-74 tahun dan 63,8\% umur >75 tahun. Sedangkan di Sumatera Barat, penyakit hipertensi termasuk ke dalam 5 penyakit yang terbanyak di alami oleh masyarakat.dan dari laporan Riset Kesehatan Dasar di Sumatera Barat di dapatkan tekanan darah tinggi pada usia lanjut yaitu sekitar $27,8 \%$. Hipertensi sebagian besar $80 \%$ di sebabkan oleh faktor idiopatik, sedangkan faktor yang dapat menjadi pencetus hipertensi sekitar $24 \%$ adalah perokok berat, $16 \%$ diabetes mellitus, dan $62 \%$ karena kolesterol tinggi. Faktor kebiasaan lain yang dapat mengakibatkan hipertensi adalah pecandu alkohol, stress tinggi, makanan tinggi natrium dan kurangnya aktifitas. Seseorang yang menderita hipertensi memiliki resiko stroke tujuh kali lebih besar dibandingkan dengan seseorang yang memiliki tekanan darah normal atau rendah.

Berdasarkan data yang di dapat dari Dinas Kesehatan Kota Padang pada Puskesmas AmbacangKecamatan Kuranji terjadi peningkatan lansia dengan hipertensi dari tahun ke tahun yaitu pada tahun 2017 sebanyak 12,1\% meningkat lagi pada tahun 2018 yaitu 15,7\%. Puskesmas AmbacangKecamatan Kuranji dari bulan Oktober-Desember2018 jumlah pasien yang berkunjung yaitu sebanyak 418 orang dengan jumlah kunjungan 1.121 kunjungan. Rata-rata kunjungan pasien hipertensi ke Puskesmas Ambacang Kecamatan Kuranjiadalah 2 kali dalam 1 minggu. Menurut penelitian Sartika (2017), penanganan hipertensi sebelumnya dilakukan dengan terapi farmakologi yaitu dengan mengkonsumsi obat anti hipertensi seperti diuretic, betabloker dan vasodilator. Beberapa penderita hipertensi menolak untuk disiplin meminum obat farmakologi karena efek samping seperti batuk, pusing, disfungsi seksual, aritmia jantung, dan retensi cairan, sehingga para penderita hipertensi memilih pengobatan non farmakologi dalam mengontrol tekanan darah untuk mengurangi efek samping tersebut.

Selain terapi farmakologi, sekarang juga telah banyak dikembangkan terapi non farmakologi dalam penanganan pasien hipertensi yaitu dengan mengubah gaya hidup sehari-hari, seperti berolah raga secara teratur, mengubah pola makan, dan dapat dilakukan dengan melakukan terapi relaksasi. Penenangan diri pada terapi relaksasi dapat menstabilkan tekanan darah yang didasarkan pada cara kerja sistem saraf simpatis dan parasimpati. Terapi relaksasi meliputi relaksasi nafas dalam, relaksasi progresif, terapi musik, dan terapi religius. Terapi religius yang digunakan untuk mengatasi hipertensi yaitu dengan melakukan terapi relaksasi Benson. Keuntungan dari relaksasi religius ini selain mendapatkan manfaat dari relaksasi juga mendapatkan manfaat dari penggunaan keyakinan seperti menambah keimanan dan mendapatkan pengalaman-pengalaman transendensi dan selain metodenya yang sederhana karena hanya bertumpu pada usaha nafas dalam yang diselingi dengan permohonan pada Tuhan Yang Maha Kuasa, teknik ini juga dapat dilakukan kapan saja dan dimana saja tanpa membutuhkan ruangan yang khusus.. 
Terapi relaksasi Benson merupakan terapi religius yang melibatkan faktor keyakinan agama, yang dapat menyelesaikan relaksasi semua otot dan merupakan upaya untuk memusatkan perhatian pada suatu fokus dengan menyebutkan berulang-ulang kalimat ritual dan menghilangkan berbagai fikiran yang mengganggu. Relaksasi Benson dapat mengurangi kecemasan, mengatasi serangan hiperventilasi, mengurangi sakit kepala, nyeri punggung, angina pectoris, hipertensi gangguan tidur dan mengurangi stress. Teknik relaksasi Benson merupakan teknik latihan nafas. Dengan latihan nafas yang teratur dan dilakukan dengan benar, tubuh akan menjadi lebih rileks, menghilangkan ketegangan saat mengalami stress dan bebas dari ancaman. Perasaan rileks akan diteruskan ke hipotalamus untuk menghasilkan Corticotropin Releasing Factor (CRF). Selanjutnya CRF merangsang kelenjar pituitary untuk meningkatkan produksi Proopioidmelanocortin (POMC) sehingga produksi enkephalin oleh medulla adrenal meningkat. Kelenjar pituitary juga menghasilkan $\beta$ endorphin sebagai neurotransmitter. Dengan meningkatnya enkephalin dan $\beta$ endorphin, pasien akan merasa lebih rileks dan nyaman.

\section{B. METODE PENELITIAN}

Jenis penelitian ini yaitu Eksperimental dengan pendekatan One Group Pratest Postest Desingn (Notoatmodjo, 2010). Bertujuan untuk mengetahui perubahan tekanan darah dengan cara melakukan pengukuran tekanan darah sebelum diberikan terapi Benson dan sesudah diberikan terapi benson. Populasi dalam penelitian ini berjumlah 418 orang. Jumlah sampel sebanyak 15 orang penderita hipertensi dengan teknik pengambilan sampel Purposive Sampling. Penelitian dilakukan pada bulan September- Desember 2019.Instrumen yang digunakan dalam penelitian ini yaitu Tensi meteruntuk pengukuran tekanan darah dan tasbih untuk terapi Benson. Analisa data pada penelitian ini menggunakananalisa data univariatdan bivariat,analisa univariat menggambarkan untuk melihat kadar tekanan darah sebelum dan sesudah pemberian terapi Benson, sedangkan analisis bivariatnya menggunakan uji paired samples $t$ test.

\section{HASIL DAN PEMBAHASAN}

1. Karakteristik Responden

Tabel 1. Karakteristik Responden Berdasarkan Jenis Kelamin

\begin{tabular}{lcc} 
Jenis Kelamin & Frekuensi & \% \\
\hline Laki-laki & 2 & 13.3 \\
Perempuan & 13 & 86.7 \\
\hline Total & 15 & 100.0 \\
\hline
\end{tabular}

Berdasarkan tabel diatas dapat diketahui bahwa dari karakteristik jenis kelamin, hampir seluruhnya $(86,7 \%)$ responden berjenis kelamin perempuan.

Tabel 2. Karakteristik Responden Berdasarkan Umur

\begin{tabular}{ccc}
\hline Umur (tahun) & Frekuensi & \% \\
\hline 60 & 1 & 6.7 \\
61 & 2 & 13.3 \\
62 & 2 & 13.3 \\
63 & 1 & 6.7 \\
65 & 2 & 13.3 \\
66 & 2 & 13.3 \\
67 & 1 & 6.7 \\
68 & 1 & 6.7 \\
73 & 1 & 6.7 \\
76 & 1 & 6.7 \\
\hline
\end{tabular}




\begin{tabular}{rcc}
\hline 80 & 1 & 6.7 \\
\hline Total & $\mathbf{1 5}$ & $\mathbf{1 0 0}$ \\
\hline
\end{tabular}

Berdasarkan tabel diatas dapat diketahui bahwa dari karakteristik umur responden, termuda 60 tahun dan tertua 80 tahun.

Tabel 3. Karakteristik Responden Berdasarkan Pendidikan

\begin{tabular}{lcc}
\hline Pendidikan & Frekuensi & \% \\
\hline SD & 3 & 20.0 \\
SMP & 6 & 40.0 \\
SMA & 5 & 33.3 \\
PT & 1 & 6.7 \\
\hline Total & 15 & 100.0 \\
\hline
\end{tabular}

Berdasarkan table diatas dapat diketahui bahwa dari karakteristik Pendidikan responden, hamper separoh (40.\%) responden berpendidikan SMP.

\section{Rerata Tekanan Darah Sistole Responden Sebelum Terapi Relaksasi Benson \\ Tabel 4.Rerata Tekanan Darah Sistole Responden Sebelum Dilakukan Terapi Relaksasi Benson}

\begin{tabular}{cccccc}
\hline Tekanandarah systole & N & Mean & SD & Min & Mak \\
\hline Sebelum & 15 & 160,67 & 4.577 & 155 & 170
\end{tabular}

Berdasarkan tabel diatas didapatkan rata-rata tekanan darah systole sebelum dilakukan terapirelaksasi Benson adalah 160,67 $\mathrm{mmHg}$ dengan standard deviasi 4,57. Rerata-rata tekanan darah systole sebelum dilakukan terapi relaksasi Benson adalah 160,67 $\mathrm{mmHg}$ dengan standard deviasi 4,57. Hasil penelitian ini didukung oleh penelitian yang dilakukan oleh Sukarmin (2015) tentang pengaruh Terapi Relaksasi Benson terhadap tekanan darah systole pada pasien hipertensi di rumahsakit daerah kudus didapatk anbahwa rata-rata tekanan darah systole responden sebelum diberikan perlakuan terapi relaksasi Benson adalah $153,75 \mathrm{mmHg}$. Kepekaan terhadap hipertensi akan meningkat seiring dengan bertambahnya umur seseorang. Individu yang berumur di atas 60 tahun, 50-60\% mempunyai tekanan darah lebih besar atau sama dengan 140/90 mmHg. Hal ini merupakan pengaruh degenerasi yang terjadi pada orang yang bertambah usianya.

Faktor usia sangat berpengaruh terhadap hipertensi karena dengan bertambahnya umur maka semakin tinggi mendapatkan resiko hipertensi. Peningkatan resiko hipertensi yang berkaitan dengan factor usia sebagian besar menjelaskan tentang hipertensi systole terisolasi dan dihubungkan dengan peripheral vascular resistence (hambatan aliran darah dalam pembuluh darah perifer) dalam arteri. Selain factor usia yang mempengaruhi tekanan darah adalah jenis kelamin dimana pada wanita yang sudah menopause akan terjadi penurunan produksi hormone estrogen sehingga tekanan darah meningkat pada wanita. Marvyn (1999), mengatakan bahwa tekanan darah systole cendrung naik pada usia lanjut karena disebabkan oleh keadaan yang disebut pergeseran arteri atau dalam istilah medis adalah arteriosclerosis. Penyakit degenerative ini biasanya menyerang secara perlahan dan tanpa menimbulkan nyeri sampai tahap yang terlalu lanjut. Ini ditandai dengan penebalan dan pengurangan elastisitas dinding arteri, mengakibatkan penyempitan ruang tempat mengalirnya darah yang dikenal sebagai lumen (rongga didalam pembuluh), karena diameter lumen menyempit, tenaga yang lebih besar diperlukan untuk mendorong darah melaluinya. Jantung menanggapi dengan meningkatkan tekanan denyutnya, akibatnya tekanan darah menjadi tinggi.

\section{Rerata Tekanan Darah Sistole Responden Sesudah Terapi Relaksasi Benson Tabel 5. Rerata Tekanan Darah Sistole Responden Sesudah Dilakukan Terapi Relaksasi Benson}




\begin{tabular}{cccccc}
\hline $\begin{array}{c}\text { Tekanan darah } \\
\text { systole }\end{array}$ & N & Mean & SD & Min & Mak \\
\hline Sesudah & 15 & 153,67 & 7,188 & 150 & 165
\end{tabular}

Berdasarkan table diatas didapatkan rata-rata tekanan darah sistole sesudah dilakukan terapi relaksasi Benson adalah 153,67 $\mathrm{mmHg}$ dengan standard deviasi 7,188. Hal tersebut menunjukkan bahwa tekanan darah systole responden sesudah diberikan terapi relaksasi Benson mengalami penurunan.. Rerata-rata tekanan darahs istole sesudah dilakukan terapi relaksasi Benson adalah 153,67 mmHg dengan standard deviasi 7,188. Hal tersebut menunjukkan bahwa tekanan darah systole responden sesudah diberikan terapi relaksasi Benson mengalami penurunan. Penelitian ini hamper sama dengan penelitian yang dilakukan oleh Sartika (2017)tentang pengaruh terapi relaksasi Benson terhadap tekanan darah pada lansia penderita hipertensi dibalai PSTW Unit Budi Luhur

Yogyakarta yaitu menunjukkan bahwa rata-rata tekanan darah systole responden sesudah diberikan perlakuan terapirelaksasi Benson adalah 150,20 $\mathrm{mmHg}$. Hal tersebut menunjukkan bahwa tekanan darah respon den sesudah diberi kanterapi relaksasi Benson mengalami penurunan.

Salah satu terapi yang dapat dilakukan untuk lansia hipertensi yaitu dengan melakukan terapi relaksasi Benson. Relaksasi Benson merupakan pengembangan metode respon relaksasi dengan melibatkan factor keyakinan responden. Tekanan darah tinggi terbanyak disebabkan oleh factor penyempitan pembuluh darah yang dapat diakibatkan oleh penumpukan lipid, glukosa darah dan aktifitas hormonal sepertie pinefrin dan norepinefrin. Benson relaksasi bekerja pada sistem hormonal dengan cara menurunkan aktifitas epinefrin dan norepinefrin yang dapat dipicu oleh stress yang berlebihan.

Proses pernafasan pada relaksasi Benson merupakan proses masuknya $\mathrm{O}_{2}$ melalui saluran nafas kemudian masuk ke paru dan diproses ke dalam tubuh, kemudian selanjutnya diproses dalam paru-paru tepatnya di bronkus dan diedarkan keseluruh tubuh melalui pembuluh vena dan nadi untuk memenuhi kebutuhan akan $\mathrm{O}_{2}$. Apabila $\mathrm{O}_{2}$ dalam tercukupi maka manusia berada dalam kondisi seimbang. Kondisi ini akan menimbulkan keadaan relaks secara umum pada manusia.

\section{Perbedaan Rerata Tekanan Darah Sistole Responden Sebelum dan Sesudah dilakukan Terapi Relaksasi Benson}

Berdasarkan table diatas didapatkan rata-rata tekanan darah systole sebelum dilakukan terapi relaksasi Benson pada lansia dengan hipertensi di Kelurahan Lubuk Lintah RW I Kecamatan Kuranji Padang adalah 160,67 mmHg dan rata-rata tekanan darah sistole sesudah dilakukan terapi relaksasi Benson pada lansia dengan hipertensi di Kelurahan Lubuk Lintah RW I Kecamatan Kuranji Padang adalah 153,67 mmHg dengan selisih mean $7 \mathrm{mmHg}$. Berdasarkan uji statistic $t$ dependen didapatkan $p$ value $=0,000$ ( $\mathrm{p}$ value <0.05), artinya adanya pengaruh terapirelaksasi Benson terhadap tekanan darah systole pada lansia dengan hipertensi di Kelurahan Lubuk Lintah RW I Kecamatan Kuranji Padang. Berdasarkan uji statistic $t$-dependen didapatkan $p$ value $=0,000$ ( $\mathrm{p}$ value $<0.05$ ), artinya adanya pengaruh terapi relaksasi Benson terhadap tekanan darah systole pada lansia dengan hipertensi di Kelurahan Lubuk Lintah RW I Kecamatan Kuranji Padang. Menurut Martin, dalam Purwati (2012) menyatakan bahwa terapi relaksasi Benson adalah salah satu metode untuk membantu menurunkan tekanan darah. Penurunan tekanan darah disebabkan karena relaksasi ini pada prinsipnya adalah memposisikan tubuh dalam kondisi tenang, sehingga akan mengalami kondisi keseimbangan, dengan demikian relaksasi Benson yang berintikan pada pernafasan akan meningkatkan sirkulasi oksigen ke otot-otot, sehingga otot-otot akan mengendur, tekanan darah akan menurun.

Dusek dan Benson (2009) mengemukakan bahwa respon relaksasi erat kaitannya dengan axis Hipotalamus Pituitary Adrenal (HPA). Seseorang dalam keadaan relaksasi, axis HPA ini akan menurunkan kadar kortisol, epineprin, dan norepineprinyang dapat menyebabkan penurunan tekanan darah dan frekuensi nadi. Kadar kortisol dalam darah berefek dalam vasokonstriksi pembuluh darah. Penurunan kadar epineprin dan norepineprin dapat menyebabkan vasodilatasi 
pembuluh darah. Kadar epineprin dan norepineprin dalam darah bekerja langsung direseptor androgenik alfa otot polos vascular, sehingga menyebabkan vasokonstriksi. Vasodilatasi pembuluh darah yang disebabkan oleh penurunan kadar epineprin dan norepineprin ini dapat menurunkan tahan perifer total yang akan menurunkan tekanan darah. Relaksasi Benson dapat menyebabkan penurunan aktifitas sistem saraf simpatis yang akhirnya dapat sedikit melebarkan arteri dan melancarkan peredaran darah yang kemudian dapat meningkatkan transport oksigen keseluruh jaringan terutama ke perifer. Masing-masing saraf parasimpatis dan simpatis saling berpengaruh, maka dengan bertambahnya salah satu aktivitas sistem yang satu akan menghambat atau menekan fungsi yang lain. Selama sistem-sistem berfungsi normal dalam keseimbangan, bertambahnya aktivitas sistem yang satu akan menghambat atau menekan efek sistem yang lain. Relaksasi Benson akan menghasilkan frekuensi gelombang alpha pada otak yang bisa menimbulkan perasaan bahagia, senang, gembira dan percaya diri sehingga dapat menekan pengeluaran hormon kortisol, epinefrin, dan norepinefrin yang merupakan vasokonstriksi kuat pada pembuluh darah. Penekanan hormon-hormon tersebut dapat mengakibatkan dilatasi pembuluh darah yang mengakibatkan penurunan resistensi pembuluh darah sehingga hasil akhirnya terjadi penurunan tekanan darah.

\section{PENUTUP}

Rata-rata tekanan darah systole sebelum dilakukan terapi relaksasi Benson adalah 160,67 mmHg dengan standard deviasi 4,57, sedangkan rata-rata tekanan darah sistole sesudah dilakukan terapi relaksasi Benson adalah 153,67 $\mathrm{mmHg}$ dengan standard deviasi 7,188. Terdapatnya perbedaan yang signifikan antara tekanan darah sistole pada lansia dengan hipertensi sesudah dilakukan terapi relaksasi Benson dengan nilai $\mathrm{p}=0,009$. Relaksasi Benson dapat menekan produksi hormon-hormon yang merupakan vasokonstriktor pembuluh darah. Sebaiknya lansia melanjutkan pelaksanaan terapi relaksasi Benson ini secara mandiri dan dapat mengajarkannya kepada orang lain.

\section{E. DAFTARPUSTAKA}

Balitbang Kemenkes RI. 2013. Riset Kesehatan Dasar Tahun 2013.

Benson, Herbert. 2000. Herbert Benson's Relaxation Response. http://seftalbi.com/fitur/15penentu-efektifitas-seft/herbert Benson relaxation meditation.

Dalimartha, Setiawan, and dkk. 2008. Care Your Self - Hipertensi. Jakarta: Penebar Plus.

Ermawati. 2011. "Perubahan Lanjut Usia." http://www.e-jurnal.com/2011/09/perubahan-padalanjut-usia.html. .

Junaedi, Edi. 2013. Hipertensi Kandas Berkat Herbal. Jakarta: Agromedia Pustaka.

Kowalski. 2010. Terapi Hipertensi: Program 8 Minggu Menurunkan Tekanan Darah Tinggi Dan Mengurangi Resiko Serangan Jantung Dan Stroke Secara Alami. Bandung: Penerbit Qanita.

Kementerian Kesehatan Republik Indonesia. 2010. Info DATIN Hipertensi Pusat Data Dan Informasi Kementerian Kesehatan RI. Jakarta.

Lingga. 2012. Bebas Hipertensi Tanpa Obat. Jakarta: Agromedia Pustaka.

Maryam. 2008. Mengenal Usia Lanjut Dan Perawatannya. Jakarta: Salemba Medika.

Purwati, Dewi, Maria Suryani, and Mamat Supriyono. 2012. "Perbedaan Tekanan Darah Sebelum Dan Sesudah Terapi Relaksasi Benson Pada Pasien Hipertensi, Di Wilayah Kerja Puskesmas Karangayu Semarang.” STIKES Telogorejo Semarang.

P2PTM Kemenkes RI. 2019. "Hari Hipertensi Dunia 2019." http://p2ptm.kemenkes.go.id/kegiatan-p2ptm/pusat-/hari-hipertensi-dunia-2019-know-yournumber-.

Salafudin, and Sri Handayani. 2015. "Pengaruh Teknik Relaksasi Benson Terhadap Tekanan Darah Pada Lansia Penderita Hipertensi Di Posyandu Lansia Larasati Dusun Wiyoro Baturetno Banguntapan Bantul Yogyakarta." Jurnal Kesehatan SAMODRA ILMU 6(2).

Sartika, Oktarina Dewi. 2017. "Pengaruh Relaksasi Benson Terhadap Penurunan Tekanan Darah 
Pada Lansia Penderita Hipertensi Di Balai PSTW Unit Budi Luhur Yogyakarta." Universitas Aisyiyah Yogyakarta.

Sukarmin, and Rizka Himawan. 2015. "Relaksasi Benson Untuk Menurunkan Tekanan Darah Pasien Hipertensi Di Rumah Sakit Daerah Kudus." Jurnal Ilmu Keperawatan dan Kebidanan 6(3).

Sutrisno. 2005. Stroke, You Must Know Before You Get Its. Jakarta: Gramedia.

Sutrasni. 2012. Hipertensi. Jakarta: Gramedia. 